\title{
Optimalisasi Pemanfaatan Zakat Profesi Kantor Kementerian Agama Kabupaten Kediri Di Sektor Pendidikan
}

\section{Mukhsapak, ${ }^{1}$ Reza Ahmad Zahid ${ }^{2}$}

1 Pascasarjana Institut Agama Islam Tribakti Kediri, 2Institut Agama Islam Tribakti Kediri, 11mcosurabaya@gmail.com,2zahidrezaahmad66@gmail.com

\begin{abstract}
Zakat has great potential to be used to support development in the aspect of developing religious moral values through education. The Ministry of Religion of Kediri Regency seeks to apply Law number 23 of 2011 article 15 paragraph (1) in the context of implementing zakat management in order to improve education. In this study, the authors used descriptive qualitative research. The results of the study can be concluded, in channeling zakat for education in the Ministry of Religion Kediri is appropriate and refers to the distribution of zakat for the sabilillah class. Where all people who take the path of Allah, fight for His religion, both through seeking knowledge and who take up the sword, are equally entitled to receive Zakat. And the result, being able to help children who want to drop out of school because of their parents' unstable economy.
\end{abstract}

Keywords: Optimization of Zakat, Professional Zakat, Education Sector

\begin{abstract}
Abstrak
Zakat berpotensi besar digunakan untuk menunjang pembangunan dalam aspek pengembangan peningkatan nilai-nilai moral keagamaan melalui pendidikan. Kementerian Agama Kabupaten Kediri berusaha menerapkan Undang-undang nomor 23 tahun 2011 pasal 15 ayat (1) dalam rangka pelaksanaan pengelolaan zakat pada untuk meningkatkan pendidikan. Dalam penelitian ini, penulis menggunakan penelitian kualitatif diskrptif. Hasil penelitian dapat disimpulkan, dalam menyalurkan zakat untuk pendidikan Kemenag Kabupaten Kediri sudah sesuai dan merujuk pada penyaluran zakat untuk golongan sabilillah. Dimana semua orang yang menempuh jalan Allah, memperjuangkan agama-Nya, baik melalui menuntut ilmu maupun yang mengangkat pedang, sama-sama berhak untuk menerima zakat. Dan hasilnya, mampu menolang anak-anak yang hendak putus sekolah karena ekonomi orang tuanya yang tidak stabil.
\end{abstract}

Kata Kunci: Optimalisasi Zakat, Zakat Profesi, Sektor Pendidikan

\section{Pendahuluan}

Zakat adalah merupakan salah satu kewajiban individual atau fardlu ain dengan syarat tertentu dalam Islam.

Kewajiban ini sebagaimana juga kewajiban-kewajiban lainnya seperti, 
sholat, puasa, dan ibadah haji yang harus ditunaikan oleh umat Islam.

Berbeda dari kewajiban-kewajiban lainnya, kewajiban zakat juga berarti perwujudan kongrit dari hubungan manusia yang positif. Dana yang dikeluarkan dari zakat sama sekali bukan untuk Alloh namun dana tersebut dikelola dan didayagunakan semat-mata untuk kepentingan manusia sesuai dengan ketentuan dan syarat-syarat tertentu antara lain: pengentasan kemiskinan, beasiswa, modal kerja produktif, peningkatan kualitas hidup, pembangunan sarana umum, seperti, masjid pesantren, yayasan pendidikan, rumah sakit, panti asuhan, dan lain-lain.

Sejatinya, zakat memiliki dua dimensi sekaligus. Pertama, dimensi vertikal sebagai kewajiban mutlak ('ibadah mahdah) seorang hamba kepada perintah Allah. Kedua, dimensi horisontal sebagai seorang hamba terhadap harta yang dimiliki dan terhadap masyarakat, sehingga zakat juga disebut sebagai 'ibadah māliyyah

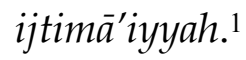

Oleh karena itu di samping dimaksudkan untuk pensucian jiwa (tazkiyah alnafs), dan pensucian harta (tazkiyah al-māl), zakat dimaksudkan untuk pensucian hubungan sosial (tazkiyah al-jamā'ah). Dengan tiga fungsi tersebut zakat berperan sebagai penyeimbang tata hubungan dalam

${ }^{1}$ Mahmud Syaltut, Islām; 'Aqidah wa Syari'ah, Mahmud Syaltut, Min Hudā Al-Qur'ān, (Kairo:

Dar-Al-Kitab Al-'Arabi, tt), h. 216-217

2 Departemen Agama RI, Pola Pembinaan

Lembaga Pengelola Zakat Di Indonesia, Direktorat Jendral Bimbingan Masyarakat Islam dan kehidupan umat manusia, yaitu antara manusia dengan alam benda, manusia dengan alam spiritual dan manusia dengan habitat sosialnya. Dalam konteks inilah, penting melihat penyaluran zakar untuk kepentingan pendidikan.

Dengan dikeluarkan Undangundang Republik Indonesia Nomor 23 Tahun 2011 tentang Pengelolaan Zakat, maka diharapkan pengelolaan zakat di tanah air akan menjadi lebih baik, apalagi dalam undang-undang tersebut pemerintah berkewajiban memberikan perlindungan, pembinaan, dan pelayanan kepada muzakki, mustahiq, dan amil zakat. $^{2}$

Jika dilihat sejarah perjalanan zakat, terdapat usaha penyempitan makna. Zakat seolah-olah hanya merupakan kewajiban individu dan dilaksanakan dalam rangka menggugurkan kewajiban individu terhadap perintah Allah ini. Sehingga zakat menjadi apa yang sering disebut sebagai ibadah mahdhah individu kaum muslimin. Padahal, zakat mempunyai peranan dalam membangun peradaban dunia. ${ }^{3}$

Kementerian Agama Kabupaten menyadari hal ini. Untuk itu, hasil pengelolaan zakat pun didistribusikan pada kemajuan pendidikan di lingkup kerjanya. Meski demikian, pihak Baznas mengakui bahwa sektor pendidikan oleh lembaga pengelola zakat meski masih memiliki prosentase lebih kecil jika

Penyelenggaraan Haji Direktorat Pengembangan Zakat dan Wakaf, (Jakarta: Departeman Agama), h. 11

${ }^{3}$ Www.kompasiana.com "Zakat dan Kamajuan Peradaban diakses pada tanggal 26 oktober 2018 
dibandingkan dengan alokasi untuk pemberdayaan ekonomi berupa pemberian modal, sangat membantu masyarakat miskin dalam mengakses pendidikan. Dalam konteks inilah, penelitian ini mengambil tema optimalisasi zakat profesi dan bidang pendidikan.

\section{Metode}

Penelitian ini menggunakan pendekatan kualitatif karena obyek yang diteliti berlangsung dalam latar yang wajar dan bertujuan untuk mengetahui, memahami, dan menghayati dengan seksama dan secara lebih mendalam tentang pendayaguanaan zakat profesi untuk lembaga pendidikan di Kabupaten Kediri. Penelitian ini yang menghasilkan data deskriptif berupa data-data tertulis atau lisan dari orang-orang atau perilaku yang dapat diamati. ${ }^{4}$

Karakteristik utama studi multi kasus adalah apabila peneliti meneliti dua atau lebih subjek, latar atau tempat penyimpanan data. Langkah-langkah penelitian studi multi kasus yang akan ditempuh dalam penelitian ini adalah sebagai berikut:

1. Melakukan pengumpulan data pengelolaan zakat profesi dalam sektor pendidikan di Kementerian Agama Kabupaten Kediri yang mana penelitian akan dilakukan sampai pada tingkat kejenuhan data,

\footnotetext{
${ }^{4}$ Moleong, Lexy J. 2010:4. Metodologi Penelitian Suatu Pendekatan Edisi Revisi. Bandung: PT Remaja Rosdakarya.

${ }^{5}$ KH.M. Syukri Ghozali dkk, , Pedoman Zakat, Proyek Pembinaan zakat dan Waqaf, (Jakarta: LKIs, 1990), hl.193
}

2. Melakukan analisis.

3. Mengambil kesimpulan dari analisis terhadap tiga kasus tersebut.

Adapun teknik pengumpulan data yang peneliti gunakan adalah observasi partisipan, wawancara, dan dokumentasi.

\section{Hasil Penelitian dan Pembahasan}

\section{Pendayagunaan Zakat Profesi}

\section{Kementerian Agama Kabupaten Kediri}

\section{Sektor Pendidikan}

Pendayagunaan zakat adalah cara atau usaha agar dana zakat mampu mendatangkan hasil atau bermanfaat. ${ }^{5}$ Pendayagunaan zakat sebagaimana pasal 27 ayat 1 Undang-undang Republik Indonesia nomor 23 tahun 2011 tentang pengelolaan zakat, yaitu zakat dapat didayagunakan untuk usaha produktif dalam rangka penanganan fakir miskin dan peningkatan kualitas umat. ${ }^{6}$

Keberhasilan zakat tergantung kepada Pendayagunaan pemanfaatannya. Walaupun seorang wajib zakat (muzakki) mengetahui dan mampu memperkirakan jumlah zakat yang akan ia keluarkan, tidak dibenarkan ia menyerahkannya kepada sembarang orang yang ia sukai. Zakat harus diberikan kepada yang berhak (mustahiq) yang sudah ditentukan menurut agama. ${ }^{7}$

Penyerahan yang benar adalah melalui badan amil zakat. Walaupun demikian kepada amil zakat manapun

${ }^{6}$ Undang-undang Republik Indonesia Nomor 23 Tahun 2011 tentang Pengelolaan Zakat, (Kediri, digandakan oleh: Kantor Kementerian Agama Kabupaten Kediri)

${ }^{7}$ Achnad Sunarto,, Risalah zakat puasa dan haji, (Jakarta: Amanah, 2002), h. 49 
tetap terpikul kewajiban untuk mengefektifkan pendayagunaannya. Pendayagunaan yang efektif ialah efektif manfaatnya (sesuai dengan tujuan) dan jatuh pada yang berhak (sesuai dengan nas) secara tepat guna. ${ }^{8}$

Tantangan terbesar dari optimalisasi zakat adalah bagaimana mendayagunakan dana zakat menjadi tepat guna dan tepat sasaran. Tepat guna berkaitan dengan program pendayagunaan yang mampu menjadi solusi terhadap problem kemiskinan. Sedangkan tepat sasaran berkaitan dengan mustahik penerima dana zakat. ${ }^{9}$ Dalam konteks Indonesia dengan jumlah penduduk miskin yang besar sekitar 40 juta jiwa, maka fakir miskin menempati prioritas pertama sebagai penerima zakat. ${ }^{10}$

Sayang program pengentasan kemiskinan yang ada kebanyakan masih bersifat karitatif (bagi-bagi habis) dan konsumtif. Program belum mengarah kepada program yang lebih produktif dan memberdayakan. Persoalan pengentasan kemiskinsan adalah bagaimana program ditujukan untuk menangani sampai akar permasalahan bukan gejalanya saja.

${ }^{8}$ Kementerian Agama RI. Panduan Organisasi Pengelola Zakat, Direktorat Jendral bimbingan masyarakat Islam direktorat pemberdayaan zakat, digandakan oleh, Kantor wilayah kementerian agama Provinsi Jawa Timur, (Surabaya: Departemen Pndidiakan Agama RI, 2015), h. 84

${ }^{9}$ H.Z. Muttaqin, Pedoman Pembantu pegawai pencatat nikah, Proyek peningkatan tenaga keagamaan direktorat jendral bimbingan masyarakat Islam dan Penyelenggara Haji
Sebagai analogi adalah sebuah hadits Rasul sebagai berikut. Diriwayatkan dari Anas bin Malik, sesungguhnya seorang laki-laki kaum Anshar mendatangi Rasulullah dan memintan sesuatu kepadanya. Rasulullah bertanya: "Apakah kamu tidak memiliki sesuatupun di rumahmu?" ia menjawab: "tentu, kain yang kami pakai sebagian, dan sebagian lainnya kami jadikan alas, dan juga gelas besar tempat kami minum air darinya." Rasullah pun berkata: " Bawalah keduanya padaku." Lalu kedua barang tersebut diberikan kepada Rasulullah saw. dan beliaupun lalu melelangnya sehingga laku sampai dua dirham. Kemudian Rasulullah berkata: "Belilah dengan dirham yang pertama ini makanan untuk kau berikan keluargamu, dan dirham lainnya belilah kapak dan kau bawa kepadaku." Rasulullah pun lalu menguatkan ikatan ranting dengan tangannya. Lalu ia berkata kepada laki-laki tersebut. "pergilah dan carilah kayu bakar, lalu juallah. Aku tidak ingin melihatmu lagi hingga lima belas hari kedepan." Lalu laki-laki tersebut mencari kayu bakar dan menjualnya. Hingga tiba saatnya, iapun mendatangi Rasulullah dengan membawa sepuluh dirham di tangannya, yang kemudian sebagian darinya ia belikan makanan. ${ }^{11}$

Dari hadist di atas dapat disimpulkan bahwa proses pengentasan

Departemen Agama RI, (Jakarta: Departemen Pndidiakan Agama RI, 2014), h. 114

10 H. Nasrun Haroen," Panduan Organisasi Pengelola Zakat, Kementerian Agama RI Direktorat Jendral bimbingan Masyarakat Islam Direktorat Pemberdayaan Zakat Jakarta: Gramedia, 2010), h. 84

${ }^{11}$ KH.M.Syukron Ghozali dkk, Pedoman Zakat, Proyek Pembinaan Zakat Dan Waqaf, (Jakarta: Pustaka Pelajar 1991). h. 193 
kemiskinan adalah sebuah proses pemberdayaan yang sedikitnya meliputi penyadaran akan potensi, adanya pendampingan, akses terhadap pasar, proses panjang dan terlebih dahulu memperioritaskan pemenuhan akan kebutuhan dasar mustahik. ${ }^{12}$ Pendayagunaan zakat Kantor Kementerian Agama Kabupaten Kediri adalah merupakan kegiatan pengelolaan zakat, yaitu kegiatan perencanaan, pelaksanaan, dan pengoordinasian dalam pengumpulan, pendistribusian, dan pendayagunaan zakat. ${ }^{13}$

Pada data pendistribusian zakat Kantor kementerian Agama Kabupaten
Kediri semester II dari bulan desember sampai bulan pebruari tahun 2018/2019 totalnya adalah Rp. 89.040 .000 dan didistribusikan untuk beberapa sektor diantaranya bantuan untuk fakir miskin Desa binaan, bantuan modal usaha untuk fakir miskin, bantuan untuk pembangunan masjid, bantuan untuk renovasi masjid, bantuan untuk guru honorer/sabilillah, bantuan untuk guru ngaji/sabilillah, bantuan untuk siswa miskin, namun yang paling besar adalah bantuan untuk guru honorer/sabilillah, untuk lebih jelasnya lihat tabel dibawah ini: ${ }^{14}$

Tabel Pendistribusian Zakat Semester Ii Tahun 2018/2019

\begin{tabular}{|c|c|}
\hline PENDISTRIBUSIAN & JUMLAH \\
\hline Bantuan untuk fakir miskin desa binaan Penyuluh Agama & $\begin{array}{ll}\mathrm{Rp} & 8.500 .000 \\
\end{array}$ \\
\hline Bantuan modal usaha bagi fakir miskin jamaah majlis & Rp 3.000 .000 \\
\hline Bantuan Pembangunan Masjid Baitur Rohman Dusun & Rp $\quad 3.000 .000$ \\
\hline Bantuan untuk siswa miskin pada MIN 3 Kediri & $\operatorname{Rp} \quad 3.000 .000$ \\
\hline Bantuan untuk guru honorer/sabilillah Pada satker & Rp 17.000 .000 \\
\hline Bantuan untuk guru honorer/sabilillah pada satker & Rp 13.500 .000 \\
\hline Bantuan untuk guru ngaji/sabililah dan fakir miskin desa & $\begin{array}{ll}1 & 3.000 .000\end{array}$ \\
\hline Bantuan untuk renovasi masjid daerah binaan penyuluh & $\begin{array}{ll}\mathrm{Rp} & 3.000 .000\end{array}$ \\
\hline Bantuan untuk fakir miskin desa binaan Penyuluh Agama & $\begin{array}{ll}\mathrm{Rp} & 2.000 .000 \\
\end{array}$ \\
\hline Bantuan untuk fakir miskin/eks lokalisasi binaan penyuluh & Rp 7.500 .000 \\
\hline Bantuan untuk siswa miskin pada MTsN 1 Kediri & Rp 7.600 .000 \\
\hline Bantuan untuk siswa miskin pada MTsN 7 Kediri & $\operatorname{Rp} \quad 6.500 .000$ \\
\hline Bantuan untuk siswa miskin pada MIN 2 Kediri & Rp 3.200 .000 \\
\hline Bantuan untuk guru ngaji/sabilillah dan fakir miskin & Rp $\quad 3.000 .000$ \\
\hline Bantuan untuk siswa miskin pada MTsN 8 Kediri & $\begin{array}{ll}\mathrm{Rp} & 1.500 .000 \\
\end{array}$ \\
\hline Bantuan untuk siswa iskin pada MAN 5 Kediri & $\begin{array}{ll}\mathrm{Rp} & 3.300 .000\end{array}$ \\
\hline Bantuan untuk tenaga kebersihan, penjaga malam dan & $\mathrm{Rp} \quad 440.000$ \\
\hline JUMLAH & Rp 89.040 .000 \\
\hline
\end{tabular}

12 H. Nasrun Haroen, Panduan Organisasi Pengelola Zakat, Kementerian Agama RI Direktorat Jendral Bimbingan Masyarakat Islam Direktorat Pemberdayaan Zakat, (Jakarta: Pustaka Pelajar, 2010), h. 86
${ }_{13}$ Undang-undang Republik Indonesia nomor 23 Tahun 2011 tentang Pengelolaan Zakat (2012) di gandakan oleh Kantor Kementerian Agama Kabupaten Kediri

${ }^{14}$ Dokumentasi pendistribusian zakat Kantor Kementerian Agama Kabupaten Kediri 
Pendistribusian dana zakat Kantor Kementerian Agama Kabupaten Kediri tersebut diatas di petakan atau di kelompokkan menjadi beberapa sektor kegiatan diantaranya yang peneliti bahas adalah di sektor pendidikan, di sektor pendidikan bantuan untuk siswa miskin, sejumlah Rp. 25.100 .000 atau $28 \%$. ${ }^{15}$

\section{Pemetaan Kontribusi Zakat}

Pemetaan kontribusi zakat Kantor Kementerian Agama Kabupaten Kediri ke beberapa sektor, namun dalam penelitian ini yang akan di bahas adalah khususnya disektor pendidikan, karena pendidikan harus ada pada manusia dan merupakan hakikat hidup manuasia. ${ }^{16}$ Mengingat begitu pentingnya dunia pendidikan yang memiliki kontribusi besar terhadap kemampuan dan pengalaman manusia. ${ }^{17}$

Adapun dana pemetaan kontribusi zakat Kantor Kementerian Agama Kabupaten Kediri yang berasal dari hasil pengumpulan zakat profesi, dan infaq dari pegawai dan karyawan di lingkungan Kantor Kementerian Agama Kabupaten Kediri. ${ }^{18}$ Sebagaimana dalam Undang-Undang Nomor 23 Tahun 2011 tentang Pengelolaan Zakat pasal 1 ayat 1 berbunyi pengelolaan zakat adalah

\footnotetext{
${ }^{15}$ Dokumentasi Pendistribusian Zakat Kantor Kementerian Agama Kabupaten Kediri

16 H. Ramayulis, (2015), Filsafat pendidikan Islam, Analisis Filosofis Sistem Pendidikan Islam, Kalam Mulia, (Jakarta: Pustaka Pelajar, 2015), h. 5

17 Teguh Triwiyanto, , Pengantar pendidikan, Bumi Aksara (Jakarta: Bumi Aksara,2015), h. 75
}

kegiatan perencanaan, pelaksanaan, pengoordinasian dalam pengumpulan, pendistribusian, dan pendayagunaan zakat. ${ }^{19}$

Pemetaan kontribusi zakat Kantor Kementerian Agama Kabupaten Kediri di sektor pendidikan diantaranya adalah sebagai berikut:

a. Madrasah Ibtidaiyah Negeri 2 Doko

Madrasah Ibtidaiyah Negeri 2 Doko yang terletak di jalan kilisuci Desa Doko kecamatan Ngasem berbatasan dengan sebelah utara kecamatan Gurah, sebelah selatan kecamatan wates, sebelah barat kecamatan Kota Kediri dan sebelah timur kecamatan plosoklaten, sarana prasarana cukup memadai, mulai dari gedung sekolah, perpustakaan, musholla, aula, lapangan olah raga, disamping tempatnya juga strategis karena dekat dengan kota Kediri, jumlah murid sebanyak 824 siswa dan siswi. 20

Madrasah Ibtidaiyah Negeri 2 Doko mendapat bantuan dana zakat untuk siswa miskin karena di sekolah tersebut terdapat siswa miskin yang masuk dalam kelompok orang yang berhak menerima zakat atau mustahik yang dikenal dengan sebutan delapan asnaf.

\footnotetext{
${ }^{18}$ Dokumentasi Pendistribusian Zakat Kantor Kementeria Agama Kabupaten Kediri

${ }_{19}$ Udang-undang Republik Indonesia Nomor 23 Tahun 2011 tentang Pengelolaan Zakat, di gandakan oleh Kantor Kementerian Agama Kabupaten Kediri.

${ }^{20}$ Dokumentasi Madrasah Ibtidaiyah Negeri 2 Doko Sabtu tanggal 13 Juli 2019
} 
b. Madrasah Ibtidaiyah Negeri 3 Ploso Lor

Madrasah Ibtidaiyah Negeri 3 Ploso Lor, yang terletak di Desa Ploso Lor Kecamatan Plosoklaten Kabupaten Kediri, yang berbatasan dengan sebelah utara kecamatan gurah, sebelah selatan kecamatan ngancar, sebelah barat kecamatan wates, dan sebelah timur kecamatan puncu, sarana prasarana cukup memadai, mulai dari gedung sekolah, perpustakaan, musholla, aula, lapangan olah raga, dan laboratorium. jumlah murid sebanyak 550 siswa dan siswi, dan jumlah guru sebanyak 32 orang. ${ }^{21}$

Madrasah Ibtidaiyah Negeri 3 Plosolor mendapatkan bantuan dana zakat karena di sekolah tersebut terdapat siswa miskin, karena masuk dalam kelompok sasaran zakat yaitu yang berhak menerima zakat atau mustahik yang dikenal dengan sebutan delapan asnaf.

c. Madrasah Tsanawiyah Negeri 1 Pare.

Madrasah Tsanawiyah Negeri 1 Pare, yang berbatasan di sebelah utara Kecamatan Pelemahan, sebelah selatan Kecamatan Kepung, sebelah barat Kecamatan Pagu, sebelah timur Kecamatan Kandangan, sarana prasarana cukup memadai, mulai dari gedung sekolah, perpustakaan, laboratorium, musholla, aula, lapangan olah raga, jumlah siswa sebanyak 1.061 siswa dan siswi. $^{22}$

21 Dokumentasi Madrasah Ibtidaiyah negeri 3 Plosolor Sabtu tanggal 13 Juli 2019

22 Dokumentasi Madrasah Tsanawiyah Negeri 1 Pare, Sabtu tanggal 13 Juli 2019
Madrasah Ibtidaiyah Negeri 1 Pare mendapat bantuan dana zakat untuk siswa miskin karena terdapat siswa miskin di sekolah tersebut, sehingga masuk dalam kelompok orang yang berhak menerima zakat atau mustahiq yang dikenal dengan sebutan delapan asnaf,

d. Madrasah Tsanawiyah Negeri 7 Kepung

Madrasah Tsanawiyah Negeri 7 Kepung, yang berbatasan di sebelah utara Kecamatan Kandangan, sebelah selatan Kecamatan Puncu, sebelah barat Kecamatan Pare, sebelah timur Kabupaten Malang, sarana prasarana cukup memadai, mulai dari gedung sekolah, perpustakaan, musholla, aula, lapangan olah raga, jumlah siswa sebanyak 1.125 siswa dan siswi, 23

Madrasah Tsanawiyah Negeri 7 Kepung mendapatkan bantuan dana zakat karena di sekolah tersebut terdapat siswa miskin, karena masuk dalam kelompok sasaran zakat yaitu yang berhak menerima zakat atau mustahik yang dikenal dengan sebutan delapan asnaf,

\section{e. MadrasahTsanawiyah Negeri 8 Pagu}

Madrasah Tsanawiyah Negeri 8 Pagu, yang berbatasan di sebelah utara Kecamatan Papar, sebelah selatan Kecamatan Gurah, sebelah Barat Kecamatan Gampengrejo, sebelah timur Kecamatan Pare, sarana prasarana cukup memadai, mulai dari gedung sekolah,

${ }^{23}$ Dokumentasi Madrasah tsanawiyah negeri 7 kepung, sabtu tanggal 13 juli 2019 
perpustakaan, musholla, aula, lapangan olah raga, jumlah siswa sebanyak 1.090 siswa dan siswi, ${ }^{24}$

Madrasah Tsanawiyah Negeri 8 Pagu mendapatkan bantuan dana zakat karena di sekolah tersebut terdapat siswa miskin, karena masuk dalam kelompok sasaran zakat yaitu yang berhak menerima zakat atau mustahik yang dikenal dengan sebutan delapan asnaf,

\section{f. Madrasah Aliyah Negeri 5 Kandat}

Madrasah Aliyah Negeri 5 Kandat, yang berbatasan di sebelah utara Kecamatan Kota, selatan Kecamatan Ngadirejo, barat Kecamatan Ngadiluwih, timur Kecamatan Wates, sarana prasarana cukup memadai, mulai dari gedung sekolah, perpustakaan, laboratorium, musholla, aula, lapangan olah raga, jumlah siswa sebanyak 710 siswa dan siswi, 25

Madrasah Aliyah Negeri 5 Kandat mendapatkan bantuan dana zakat karena di sekolah tersebut terdapat siswa miskin, karena masuk dalam kelompok sasaran zakat yaitu yang berhak menerima zakat atau mustahik yang dikenal dengan sebutan delapan asnaf,

Sebagaimana yang dijelaskan dalam Al-Qur'an suat Al-Taubah ayat 60. Yang berbunyi sesungguhnya shodaqah (zakat-zakat) itu untuk orang-orang fakir, miskin, pengurus zakat,para muallaf

\footnotetext{
${ }^{24}$ Dokumentasi Madrasah Tsanawiyah Negeri 8 Pagu, Sabtu Tanggal 13 Juli 2019

25 Dokumentasi madrasah Aliyah Negeri 5 Kandat, Sabtu Tanggal 13 Juli 2019

${ }^{26}$ M.Maskur Khoir, Zakat, (Kediri: Duta Karya

Mandiri Kediri, 2003), h. 85

27 Dokumentasi Pendistribusian Zakat Semester II Bulan Desember sampai Januari
}

yang dibujuk hatinya, untuk memerdekakan budak, orang-orang yang berhutang untuk jalan Alloh, sabilillah, dan orang-orang yang sedang dalam perjalanan. ${ }^{26}$

\section{Alokasi Dana Sektor Pendidikan.}

Besaran dana yang di distribusikan Kantor Kementerian Agama Kabupaten Kediri di sektor pendidikan adalah sebesar Rp. 25.100 .000 atau 28 \% dari total pendapatan Rp. 89.040.000, yang berasal dari pengumpulan zakat profesi dan infaq pegawai dan karyawan dilingkungan Kantor Kementerian Agama Kabupaten Kediri. ${ }^{27}$

Sebagaimana pasal 1 ayat 1 Pengelolaan zakat adalah kegiatan perencanaan, pelaksanaan, dan pengoordinasian dalam pengumpulan, pendistribusian, dan pendayagunaan zakat. Adapun besaran dana yang di distribusikan Kantor Kementerian Agama Kabupaten Kediri di sector pendidikan di petakan menjadi 6 (enam) diantaranya sebagai berikut: ${ }^{28}$

\section{a. Madrasah Ibtidaiyah Negeri 2 Doko}

Madrasah Ibtidaiyah Negeri 2 Doko yang terletak di Jalan Kilisuci Desa Doko Kecamatan Ngasem, sebelah utara berbatasan dengan Kecamatan Gurah, sebelah selatan berbatasan dengan Kecamatan Wates, sebelah barat berbatasan dengan Kecamatan Kota,

Tahun 2018/2019 Kantor Kementerian Agama Kabupaten Kediri

28 Dokumentasi Pendistribusian Zakat Semester II Bulan Desember sampai Januari Tahun 2018/2019 Kantor Kementerian Agama Kabupaten Kediri 
sebelah timur berbatasan dengan Kecamatan Plosoklaten, sarana prasarana MIN 2 Doko cukup memadai mulai dari gedung sekolah, perpustakaan, musholla, aula, lapangan olah raga, jumlah murid sebnyak 824 siswa siswi. ${ }^{29}$

Madrasah Ibtidaiyah Negeri 2 Doko mendapatkan dana zakat Kantor Kmenterian Agama Kabupaten Kediri untuk bantuan siswa miskin sebesar Rp. 3.200.000, di terimakan kepada siswa miskin sebanyak 32 siswa. a. siswa Rp. 100.000.30

b. Madrasah Ibtidaiyah Negeri 3 Ploso Lor

Madrasah Ibtidaiyah Negeri 3 Ploso Lor, yang terletak di Desa Ploso Lor Kecamatan Plosoklaten Kabupaten Kediri, yang berbatasan dengan sebelah utara kecamatan gurah, sebelah selatan kecamatan ngancar, sebelah barat kecamatan wates, dan sebelah timur kecamatan puncu, sarana prasarana cukup memadai, mulai dari gedung sekolah, perpustakaan, musholla, aula, lapangan olah raga, dan laboratorium. jumlah murid sebanyak 550 siswa dan siswi, dan jumlah guru sebanyak 32 orang. ${ }^{31}$

Madrasah Ibtidaiyah Negeri 3 Ploso mendapatkan dana zakat untuk bantuan siswa miskin sebesar Rp. 3.000.000, di terimakan kepada siswa miskin sebanyak 30 siswa. sehingga a. siswa Rp. 100.000.

\footnotetext{
${ }^{29}$ Dokumentasi Madrasah Ibtidaiyah Negeri 2 Doko, pada Hari Sabtu Tanggal 13 Juli 2019

30 Dokumentasi Pendistribusian Zakat Semester II Kantor Kementerian Agama Kabupaten Kediri Bulan Desember sampai Februari 2018/2019.
}

c. Madrasah Tsanawiyah Negeri 1 Pare

Madrasah Tsanawiyah Negeri 1 Pare, yang berbatasan di sebelah utara Kecamatan Pelemahan, sebelah selatan Kecamatan Kepung, sebelah barat Kecamatan Pagu, sebelah timur Kecamatan Kandangan, sarana prasarana cukup memadai, mulai dari gedung sekolah, perpustakaan, laboratorium, musholla, aula, lapangan olah raga, jumlah siswa sebanyak 1.061 siswa dan siswi

Madrasah Tsanawiyah Negeri 1 Pare mendapatkan dana zakat untuk bantuan siswa miskin sebesar Rp. 7.600.000, di terimakan kepada siswa miskin sebanyak 76 siswa. sehingga menerima a. siswa Rp. 100.000.32

d. Madrasah Tsanawiyah Negeri 7 Kepung

$$
\text { Madrasah Tsanawiyah Negeri } 7
$$

Kepung, yang berbatasan di sebelah utara Kecamatan Kandangan, sebelah selatan Kecamatan Puncu, sebelah barat Kecamatan Pare, sebelah timur Kabupaten Malang, sarana prasarana cukup memadai, mulai dari gedung sekolah, perpustakaan, musholla, aula, lapangan olah raga, jumlah siswa sebanyak 1.125 siswa dan siswi,

$$
\text { Madrasah Tsanawiyah Negeri } 7
$$

Kepung mendapatkan dana zakat untuk bantuan siswa miskin sebesar Rp. 6.500.000, di terimakan kepada siswa miskin sebanyak 51 juga ditambah oleh

${ }^{31}$ Dokumentasi Madrasah Ibtidaiyah Negeri 3 Plosolor Sabtu Tanggal 13 Juli 2019

32 Dokumentasi Madrasah Tsanawiyah Negeri 1 Pare, Sabtu Tanggal 13 Juli 2019 
pihak sekolah sehingga diterima siswa. a. siswa Rp. 130.000.33

e. Madrasah Tsanawiyah Negeri 8 Pagu

Madrasah Tsanawiyah Negeri 8 Pagu, yang berbatasan di sebelah utara Kecamatan Papar, sebelah selatan Kecamatan Gurah, sebelah Barat Kecamatan Gampengrejo, sebelah timur Kecamatan Pare, sarana prasarana cukup memadai, mulai dari gedung sekolah, perpustakaan, musholla, aula, lapangan olah raga, jumlah siswa sebanyak 1.090 siswa dan siswi,

Madrasah Tsanawiyah Negeri 8 Pagu mendapatkan dana zakat untuk bantuan siswa miskin sebesar Rp. 1.500.000, di terimakan kepada siswa miskin sebanyak 10 sehingga menerima a. siswa Rp. $150.000 .{ }^{34}$

f. Madrasah Aliyah Negeri 5 Kandat

Madrasah Aliyah Negeri 5 Kandat, yang berbatasan di sebelah utara Kecamatan Kota, selatan Kecamatan Ngadirejo, barat Kecamatan Ngadiluwih, timur Kecamatan Wates, sarana prasarana cukup memadai, mulai dari gedung sekolah, perpustakaan, laboratorium, musholla, aula, lapangan olah raga, jumlah siswa sebanyak 710 siswa dan siswi,

Madrasah Aliyah Negeri 5 Kandat mendapatkan dana zakat bantuan untuk siswa miskin sebesar Rp. 3.300.000, di

33 Dokumentasi Madrasah Tsanawiyah Negeri 7 Kepung, Sabtu Tanggal 13 Juli 2019

34 Dokumentasi Madrasah Tsanawiyah Negeri 8 Pagu, Sabtu Tanggal 13 Juli 2019

35 Dokumentasi Madrasah Aliyah negeri 5 Kandat Sabtu Tanggal 13 Juli 2019

36 Undang-Undang Republik Indonesia Nomor 23 Tahun 2011 (2012), tentang Penegloaan terimakan kepada siswa miskin sebanyak 60 siswa sehingga a. siswa mendapatkan Rp. $130.000 .{ }^{35}$

\section{Keberhasilan Kontribusi Zakat Dalam Sektor Pendidikan}

Keberhasilan kontribusi Kantor Kementerian Agama Kabupaten Kediri yang di dalam pengelolaannya sesuai dengan pasal 1 ayat 1 Undang-undang nomor 23 tahun 2011 tentang pengelolaan zakat, yang berbunyi penegelolaan zakat adalah kegiatan perencanaan, pelaksanaan, dan pengoordinasian dalam pengumpulan, pendistribusian, dan pendayagunaan zakat. ${ }^{36}$

Keberhasilan kontribusi zakat Kantor Kementerian Agama Kabupaten Kediri di sektor pendidikan adalah baik dan berhasil. Karena dalam madrasah tersebut terdapat siswa miskinnya yang merupakan sasara penerima zakat, sebagaimana dijelaskan dalam Al-Qu'an surat At-Taubah ayat 60 Yang berbunyi, Terjemahannya adalah: sesungguhnya shodaqah (zakat-zakat) itu untuk orangorang fakir dan miskin, pengurus zakat, para muallaf yang dibujuk hatinya, untuk memerdekakan budak, orang-orang yang berhutang di jalan Alloh, sabilillah, dan orang-orang yang dalam perjalanan. ${ }^{37}$ Juga terdapat pada pasal 25 Undangundang Republik Indonesia nomor 23 tahun 2011.

Zakat, di gndakan oleh Kantor Kementerian Agama Kediri

37 H. Nasrun Haroen, Panduan Organisasi Pengelola Zakat, Kementerian Agama RI Direktorat Jendral bimbingan Masyarakat Islam Direktorat Pemberdayaan Zakat Jakarta: Gramedia, 2010), h. 84 
Dengan adanya pemetaan dan pendistribusian dan pendayagunaan zakat dari Kantor Kementerian Agama Kabupaten Kediri untuk bantuan siswa miskin di Madrasah Ibtidaiyah Negeri 2 Doko Rp.3.200.000, Madrasah Ibtidaiyah Negeri 3 Ploso Lor Rp. 3.000.000, Madrasah Tsanawiyah Negeri 1 Pare Rp. 7.600.000, Madrasah Tsanawiyah Negeri 7 Kepung Rp. 6.500.000, Madrasah Tsanawiyah Negeri 8 Pagu Rp. 1.500.000, Madrasah Aliyah Negeri 5 Kandat Rp. 3.300.000. ${ }^{38}$

Tentu dengan adaya pendistribusian dan pendayagunaan zaka Kantor Kementerian Agama Kabupaten Kediri sangat berpengaruh dan membantu kegiatan proses belajar mengajar disekolah tersebut dan bagi siswa miskin yang mendapatkan dana tersebut bisa mengurangi beban untuk keperluan sekolah.

\section{Pemetaan kontribusi zakat Kantor} Kementerian Agama Kabupaten Kediri di sektor pendidikan.

Pemetaan kontribusi zakat Kantor Kementerian Agama Kabupaten Kediri di sector pendidikan diataranya 6 (enam) Madrasah yaitu Madrasah Ibtidaiyah Negeri 2 Doko, Madrasah Ibtidaiyah Negeri 3 ploso lor, Madrasah Tsanawiyah Negeri 1 Pare, Madrasah Tsanawiyah Negeri 7 Kepung, Madrasah Tsanawiyah Negeri 8 Pagu, dan Madrasah Aliyah Negeri 5 Kandat.

Pemetaan di 6 (enam) Madrasah tersebut sudah tepat karena terdapat siswa miskinnya, sesuai dengan pasal 25 Undang-undang Republik Indonesia nomor 23 tahun 2011 tentang pengelolaan zakat, yaitu zakat wajib didistribusikan kepada mustahik sesuai dengan syari'at Islam. Sebagaimana juga dijelaskan dalam Al-Qu'an surat At-Taubah ayat 60 Yang berbunyi, Terjemahannya adalah: sesungguhnya shodaqah (zakat-zakat) itu untuk orang-orang fakir dan miskin, pengurus zakat, para muallaf yang dibujuk hatinya, untuk memerdekakan budak, orang-orang yang berhutang di jalan Alloh, sabilillah, dan orang-orang yang dalam perjalanan.

Tetapi lebik baik pemetaannya ditambah banyak dan luas lagi bahkan semua madrasah yang ada di wilayah Kabupaten Kediri baik negeri maupun swasta yang terdapat siswa miskin di madrasah tersebut sehingga mendapatkan bantuan dana zakat untuk bantuan siswa miskin Kantor Kementerian Agama Kabupaten Kediri.

Bahkan peneliti berharap ada program orang tua asuh baik dari guru ataupun orang tua siswa yang mampu dari segi ekonomi, untuk membantu meringankan beban siswa miskin tersebut, dengan cara pemetaan siswa miskin di sekolah-sekolah tersebut untuk menjadi orang tua asuh.

a. Besaran dana zakat yang di distribusikan Kantor Kementerian Agama Kabupaten di sector pendidikan.

Besaran dana zakat yang di distribusikan Kantor Kementerian

2018/2019 Kantor Kementerian Agama Kabupaten Kediri 
Agama Kabupaten Kediri di sector pendidikan sebesar Rp. 25.100.000 atau 28 $\%$ dari jumlah penerimaan Rp. 89.040 .000 ke 6 (enam) madrasah-madrasah antara lain:

Untuk bantuan siswa miskin ke Madrasah Ibtidaiyah Negeri 2 Doko sebesar Rp. 3.200.000, Madrasah Ibtidaiyah Negeri 3 Ploso Lor sebesar Rp. 3.000.000, Madrasah Tsanawiyah Negeri 1 Pare sebesar Rp. 7.600.000, Madrasah Tsanawiyah Negeri 7 Kepung sebesar Rp. 6.500.000, Madrasah Tsanawiyah Negeri 8 Pagu sebesar Rp. 1.500.000, dan Madrasah Aliyah Negeri 5 Kandat sebesar Rp. 3.300.000.

Meskipun dana yang di terima oleh 6 (enam) Madrasah-madrasah tersebut diatas hanya Rp. 25.100 .000 atau $28 \%$, namun paling tidak sudah masuk sasaran penerima zakat, karena di dalam Madrasah tersebut terdapat siswa miskin. sebagaimana dijelaskan dalam Al-Qu'an surat At-Taubah ayat 60 Yang berbunyi, Terjemahannya adalah: sesungguhnya shodaqah (zakat-zakat) itu untuk orangorang fakir dan miskin, pengurus zakat, para muallaf yang dibujuk hatinya, untuk memerdekakan budak, orang-orang yang berhutang di jalan Alloh, sabilillah, dan orang-orang yang dalam perjalanan. Juga terdapat pada pasal 25 Undangundang Republik Indonesia Nomor 23 Tahun 2011 tentang Pengelolaan Zakat.

Mengingat pentingnya dunia pendidikan dan agar lancarnya proses belajar mengajar di sekolah serta kebutuhan perlengkapan sekolah siswa yang semakin banyak dapat terpenuhi, maka sebaiknya di tambah lagi jumlah nominalnya dana zakat untuk bantuan siswa miskin di masing-masing madrasah-madrasah tersebut menjadi 50 \% bahkan lebih dari jumlah total peneriamaan Kantor Kementerian Agama Kabupaten Kediri.

Peneliti berharap di samping siswa miskin mendapatkan bantuan dana zakat dari Kantor Kementerian Agama Kabupaten Kediri juga mendapatkan bantuan dana dari orang tua asuh, sehingga siswa miskin yang ada di madrasah-madrasah tersebut kebutuhan sekolahnya bisa terpenuhi.

\section{Kontribusian zakat Kantor Kementerian Agama Kabupaten Kediri di sector pendidkan.}

Keberhasilan kontribusi Kantor Kementerian Agama Kabupaten Kediri yang di dalam pengelolaannya sesuai dengan pasal 1 ayat 1 Undang-undang nomor 23 tahun 2011 tentang pengelolaan zakat, yang berbunyi penegelolaan zakat adalah kegiatan perencanaan, pelaksanaan, dan pengoordinasian dalam pengumpulan, pendistribusian, dan pendayagunaan zakat.

Kontribusi pendistribusian dan pendayagunaan zakat Kantor Kementerian Agama Kabupaten Kediri di sector pendidikan ke Madrasah Ibtidaiyah Negeri 2 Doko Rp. 3.200.000, Madrasah Ibtidaiyah Negeri 3 Plosolor Rp. 3.000.000, Madrasah Tsanawiyah Negeri 1 Pare Rp. 7.600.000, Madrsah Tsanawiyah negeri 7 kepung $\mathrm{Rp}$. 6.500.000, Madrasah Tsanawiyah Negeri 8 Pagu Rp. 1.500.000, dan Madrasah Aliyah Negeri 5 kandat Rp. 3.300.000, 
Adapun dana yang diterima oleh siswa miskin tersebut di pergunakan untuk membeli keperluan sekolah seperti buku tulis, buku paket, buku penunjang, buku lembar kerja siswa, dan lain-lain. ini adalah merupakan pola pendayagunaan zakat konsumtif kreatif. dengan adanya pemetaan dan pendistribusian dana zakat tersebut proses belajar mengajar menjadi lebih lancar dan beban kebutuhan siswa dapat teratasi.

Akan tetapi tidaklah cukup sampai disitu, agar lebih berhasil perlu perluasan pemetaan maupun pendistribusian dana zakat kesemua madrasah-madrasah yang ada siswa miskinnya baik negeri maupun swasta yang ada di wilayah kabupaten Kediri, agar mendapatkan dana zakat untuk bantuan siswa miskin.

\section{Kesimpulan}

Penulis melakukan penelitian tentang pengelolaan zakat di kementerian Agama Kabupaten Kediri dalam bidang pendidikan. Hasilnya dapat ditarik kesimpulan sebagai berikut:

1. Pemetaan kontribusi zakat Kantor Kementerian Agama Kabupaten

Kediri di sektor pendidikan khususnya bantuan untuk siswa miskin. Madrasah Ibtidaiyah Negeri 2 Doko, Madrasah Ibtidaiyah Negeri 3 Plosolor, Madrasah Tsanawiyah Negeri 1 Pare, Madrasah Tsanawiyah Negeri 7 Kepung, Madrasah Tsanawiyah Negeri 8 Pagu, Madrasah Aliyah Negeri 5 Kandat.

2. Adapun besaran dana yang didistribusikan Kantor Kementerian Agama Kabupaten Kediri di sektor pendidikan adalah sebesar Rp. 25.100 .000 atau $28 \%$, dari total peneriamaan Rp. 89.040 .000 ke 6 (enam) Madrasah.

3. Pendidtribusian zakat Kantor Kementerian Agama Kabupaten Kediri khususnya di sector pendidikan berupa bantuan dana untuk siswa miskin, tersebut sesuai dengan pasal 27 Undang-Undang Nomor 23 Tahun 2011 yaitu zakat dapat didayagunakan untuk usaha produktif dalam rangka penanganan fakir miskin dan peningkatan kualitas umat.

4. Keberhasilan kontribusi zakat Kantor Kementerian Agama Kabupaten Kediri di sektor pendidikan berupa bantuan untuk siswa miskin sudah sangat baik. mengingat dengan adanya bantuan dana tersebut sehingga siswa dapat membeli peralatan sekolah seperti buku penunjang, buku LKS, buku tulis dan alat tulis. 


\section{Daftar Pustaka}

Departemen Agama (1997/1998). Motivasi Zakat, Jakarta: Direktorat Jendral Bimbingan Masyarakat Islam dan Urusan Haji, Direktorat agama Islam

Departemen Agama RI (2003). Pola pembinaan lembaga pengelola zakat di Indonesia, Jakarta: Direktorat Jendral Bimbingan Masyarakat Islam dan Penyelenggara Haji Direktorat Pengembangan Zakat dan Waqaf

Dokumenasi pendistribusian zakat Kantor Kementerian Agama Kabupaten Kediri Sabtu Tanggal 13 Juli 2019

Dokumentasi Madrasah Aliyah Negeri 5 Kandat (2019). Kediri: Sabtu Tanggal 13 Juli 2019

Dokumentasi Madrasah Ibtidaiyah Negeri 2 Doko (2019). Kediri: Sabtu Tanggal 13 Juli 2019

Dokumentasi Madrasah Ibtidaiyah Negeri 3 Ploso Lor (2019). Kediri: Sabtu Tanggal 13 Juli 2019

Dokumentasi Madrasah Tsanawiyah Negeri 1 Pare (2019). Kediri: Sabtu Tanggal 13 Juli 2019

Dokumentasi Madrasah Tsanawiyah Negeri 7 Kepung (2019). Kediri: Sabtu Tanggal 13 Juli 2019

Dokumentasi Madrasah Tsanawiyah Negeri 8 Pagu (2019). Kediri: Sabtu Tanggal 13 Juli 2019

H. Ramyulis (2015). Filsafat Pendidikan Islam, Analisis Filosofis Sistem Pendidikan Islam, Jakarta: Kalam Mulia

Kementerian Agama RI (2010). Panduan Organisasi Pengelola Zakat, Jakarta: Direktorat Jendral Bimbingan Masyarakat Islam Direktorat Pemberdayaan Zakat

Suwartin (2019). Bendahara UPZ penyelenggara syari'ah zakat dan waqaf Kediri: Kantor Kementerian Agama Kabupaten Kediri

Syaiful Bahri (2019). Kasi Penyelenggara Syariah Zakat dan Waqaf Kediri: Kantor Kementerian Agama Kabupaten Kediri

Syukri Ghozali dkk, (1990/1991). Pedoman Zakat, Jakarta: Proyek Pengembangan zakat dan waqaf

Teguh Triwiyanto (2015). Pengantar pendidikan, Jakarta: Bumi Aksara

Undang-undang nomor 23 tahun 2011 tentang Pengelolaan Zakat, (2012). Kediri: digandakan oleh Kantor Kementerian Agama Kabupaten Kediri 